\title{
HIGH-MOLECULAR CONNECTIONS
}

DOI - 10.32743/UniChem.2021.84.6.11859

\section{THE NEW POLYMER REAGENT FOR REMOVING THIN OIL SLICKS FROM WATER SURFACE}

Tarana Poladova Ali

Doctor of Philosophy in Chemistry, associate professor Western Caspian University Institute of Petrochemical Processes of ANAS Azerbaijan, Baku E-mail: teranepoladova@hotmail.com

Naila Guliyeva Mammadagha Doctor of Philosophy in Chemistry

Western Caspian University Azerbaijan, Baku

E-mail: nailya.kuliyeva.76@mail.ru

Nadjiba Shirinova Ahmad

Doctor of Philosophy in Chemistry

Western Caspian University Azerbaijan, Baku E-mail: shirinova_1963@mail.ru

Lala Gurbanova Maharram

Doctor of Philosophy in Chemistry Western Caspian University Azerbaijan, Baku

E-mail: lale_qurbanova@rambler.ru

Salimov Ilham Nasir

Doctor of Philosophy in physico-mathematical Sciences

Western Caspian University Azerbaijan, Baku

E-mail: selimovilham@mail.ru

\section{НОВЫЙ ПОЛИМЕРНЫЙ РЕАГЕНТ ДЛЯ УДАЛЕНИЯ ТОНКИХ НЕФТЯНЫХ ПЛЕНОК С ПОВЕРХНОСТИ ВОДЫ}

Поладова Тарана Али кызы

канд. хим. наук, доцент, Западно-Каспийский Университет, Институт Нефтехимических Проиессов НАН Азербайджана,

Республика Азербайджан, г. Баку

Гулиева Наиля Мамедага кызы Западно-Каспийский Университет Азербайджан, г. Баку

Ширинова Наджиба Ахмед кызы $\operatorname{PhD}$ (химия), Западно-Каспийский Университет, Азербайджан, г. Баку 
Салимов Ильгам Насир огль

PhD (химия), Западно-Каспийский Университет Азербайджан, г. Баку

\begin{abstract}
Complex based on octylmonoethylolammonium ethanoate and partially neutralized polyacrylic acid was synthesised. Surface activity properties of the obtained complex was investigated by tensiometric method. Solubility and specific electrical conductivity of these compounds were determined. Petroleum-collecting and dispersing properties of the synthesized complex in diluted (5\% wt. water solution) and undiluted form has been studied in waters of varying salinity (distilled, fresh and sea waters). The results showed that some of the synthesized complex could be used as petro-collecting agents for removing petroleum films from water surface.
\end{abstract}

\title{
АННОТАЦИЯ
}

Получены новые полимерные комплексы на основе солей октилмоноэтилоламмоний этаноата с частично нейтрализованной полиакриловой кислотой. Тензиометрическими измерениями выявлена высокая поверхностная активность этих продуктов на границе вода-воздух. Электрокондуктометрическим методом измерены значения удельной электропроводности водных растворов комплексов. В лабораторных условиях исследована нефтесобирающая способность полученных реагентов и показана их эффективность при удалении экологически опасных тонких пленок с водной поверхности.

Keywords: oil slicks, petrocollecting capacity, polymeric complex, surfactant, octylmonoethylolammonium ethanoate.

Ключевые слова: нефтяные пленки, нефтесобирающая способность, полимерные комплексы, реагенты, октилмоноэтилоламмоний этаноат.

As other water basins of the world, the Caspian Sea has its specific problems among which, pollution of the reservoir and related with it deterioration of the ecological situation hereabouts are the most important. The main sources of this sea pollution are petroleum-carrying sea transport and oil fields [1]. Characteristic features of pollution with petroleum and its products are contamination of all components of the environment, their dissipation in large aquatic areas, accumulation in bottom sediments and others. Petroleum slicks worsen water quality and negatively impact oxygen regime by disordering a balanced relation of the upper water layers with atmosphere [2].

Films of petroleum origin reflecting sunlight rays hinder absorption of energy by water necessary for life activity of marine inhabitants. Removal of such slicks is particularly important because more than a hundred fish species habitate in the Caspian Sea, among them $95 \%$ of the world sturgeon population.

However, a part of this petroleum remains on the water surface as slicks. These slicks can be liquidated only by using certain physico-chemical methods including an application of dispersants and collectors. Dispersing chemicals like mechanical clean-up methods have their own place in fighting oil spills. They are considered as a potential response along with mechanical containment and clean-up of oil slicks off the water surface. They decompose these slicks into tiny emulsions which are later subjected to biochemical destruction under the influence of microorganisms, wind, light, etc. The danger of the petroleum emulsified by dispersants does not exceed that of mechanically dispersed one, provided that their concentrations are equal [3].

In the past twenty years specialists of the Institute of Petrochemical Processes of National Academy of Azerbaijan have developed a lot of petroleum-dispersing and petroleum-collecting chemicals [4]. Petroleumcollecting is an accumulation of slicks into a thickened spot which is later easily removed by mechanical devices. Efficiency of petroleum-collecting and dispersing chemicals is greatly influenced by such factors as ion composition of water, type of petroleum, concentration of ions in water, thickness of petroleum slick and others.

This paper describes the results of studies on obtaining new, ecologically-safe and efficient oil slick-collecting agents based on new polymer-complex surfactants.

It was synthesized by interaction of octylmonoethylolammonium ethanoate salt with partially $(50 \%)$ neutralized polyacrylic acid (NPAA). They was taken at equimolar ratio:

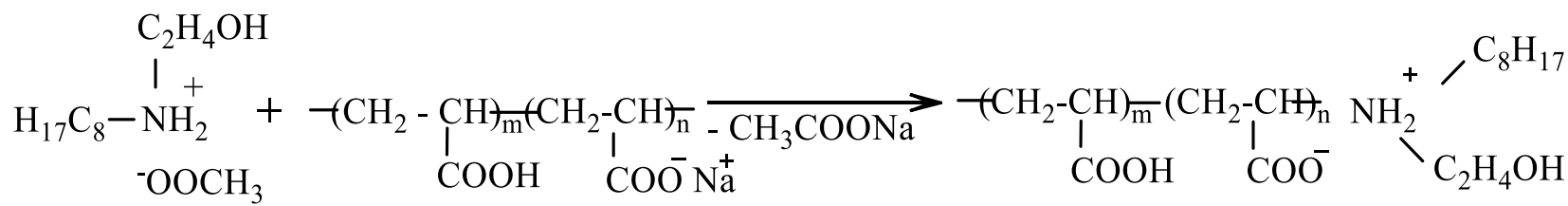


The components of reactions were mixed, closed well and placed in a thermostat at the temperature $54^{\circ} \mathrm{C}$ for a period 15-20 hours. The obtained octylmonoethylolammonium ethanoate complex polymeric salt (OMEAE) is generally viscous liquid. The final product of dark-brown color, well-soluble in ethanol and water with intense foam generation.

Composition and structure of these reagent has been identified by IR- and UV- spectroscopy methods. IRspectra was recorded by spectrometer FT-IR, Spectrum BX (Perkin Elmer) using KBr disks (Fig.1).

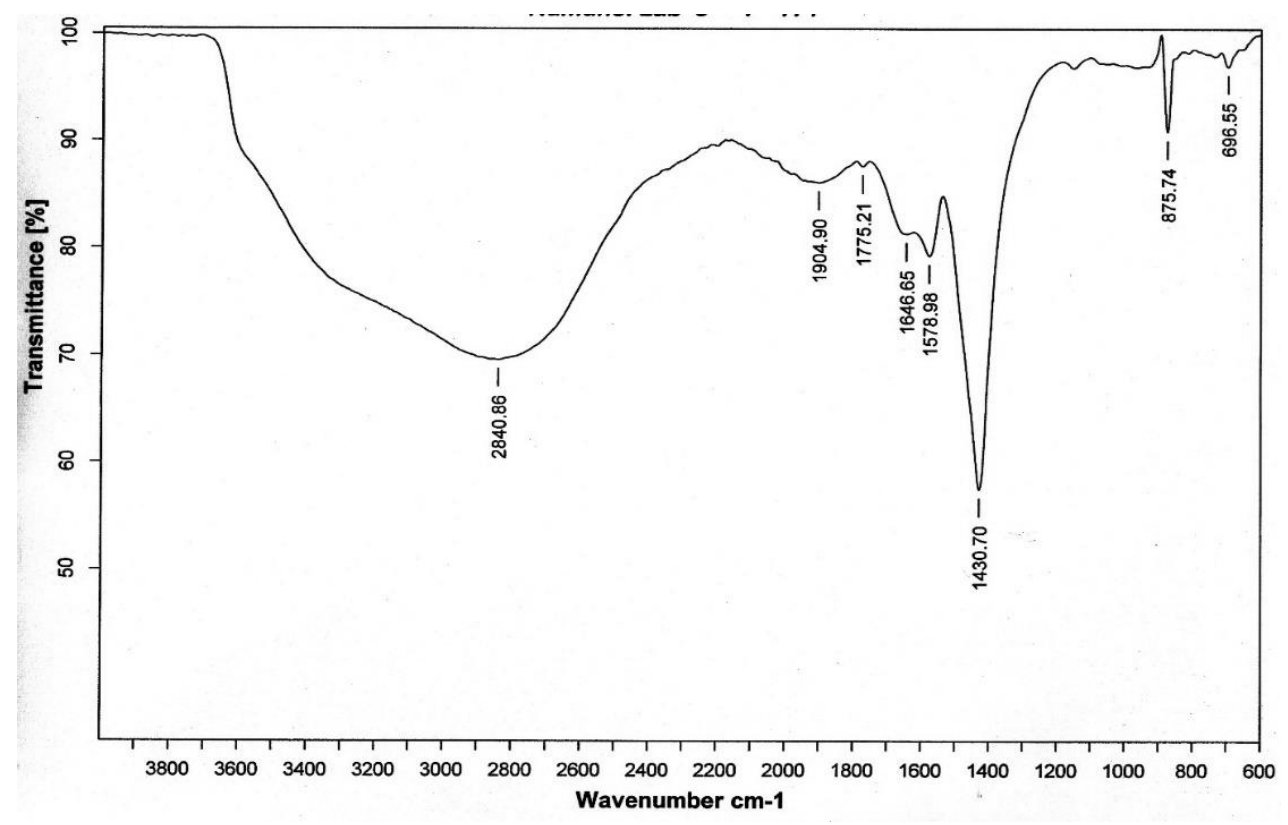

Figure 1. IR spectrum of OMEAE complex with NPAA (wavenumber $\mathrm{cm}^{-1}$ )

IR, $\mathrm{cm}^{-1}: 2840.9$ v (C-H), 1904.9 v $\left(\mathrm{N}^{+} \mathrm{H}\right), 1646.7$ v [C(O)O]- $1578.9 \delta\left(\mathrm{H}_{2} \mathrm{~N}^{+} \mathrm{CH}_{2}\right), 1430.7 \delta\left(\mathrm{N}^{+} \mathrm{H}\right)$.

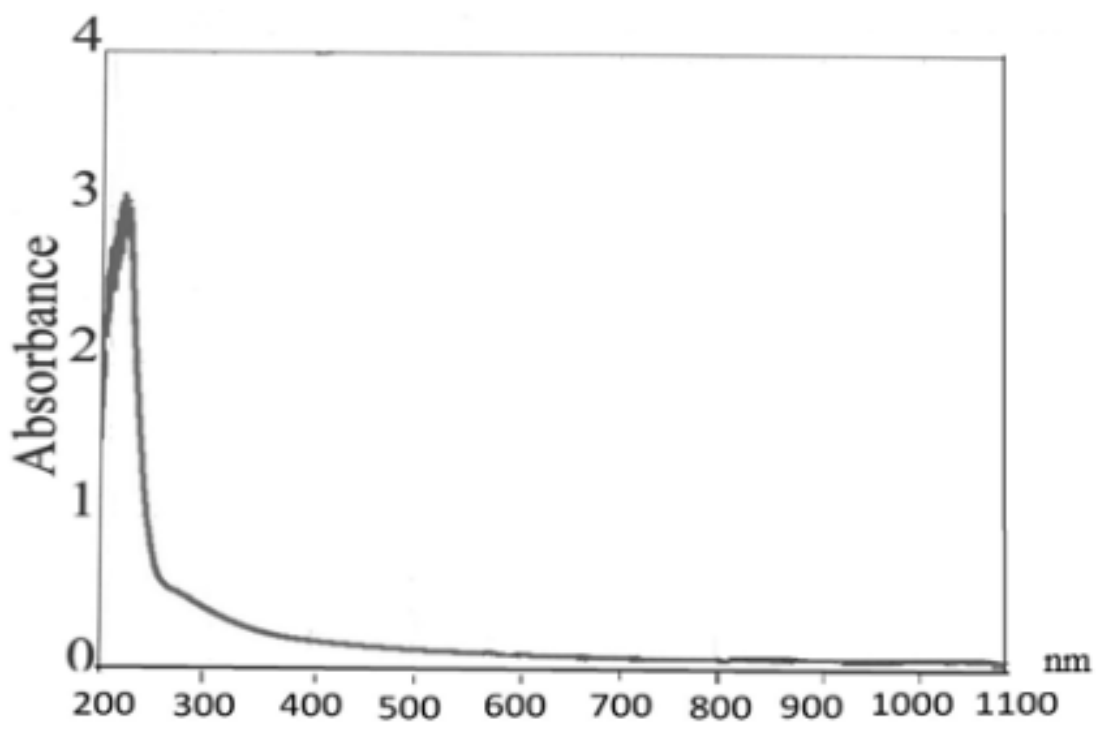

Figure 2. UV spectrum of OMEAE complex with NPAA

The UV spectrum (Fig. 2) recorded on a Specord UV VIS spectrometer shows a band at $210 \mathrm{~nm}$ due to the ammonium fragment.

Surface tension of the synthesized surfactant was determined using Du Nouy ring KSV Sigma 702 tensiometer (Israel). The measured sample was placed in a glass cell (with a double jacket) using a water bath for thermostatting. A Pt wire ring was placed inside the sample solution and gradually pulled through the liquid-air surface. Surface tension values were reported as an average over three readings with 3 min interval between measurements. The Pt wire ring was washed with water 
and flamed with a Bunsen burner between measurements.0.00025-0.1\% wt. aqueous solutions of the surfactant was prepared and after $24 \mathrm{~h}$ their surface tension was determined at $25^{\circ} \mathrm{C}$. For preparing these solutions, deionized water was used. The deviations at these measurements were less than $\pm 0.2 \mathrm{mN} / \mathrm{m}$. A high surface activity of aqueous solutions of the synthesized product was revealed (at $0.2 \%-50.8$, at $0.7 \%-40.9 \mathrm{mN} / \mathrm{m}$; without surfactant $72.0 \mathrm{mN} / \mathrm{m}$ ).

Specific electrical conductivity- $\kappa$ values of the aqueous solutions of the polymer complex has been determined using Anion-402 conductometer (Russia). After $48 \mathrm{~h}$ since preparation of $0.001-0.1 \%$ wt. aqueous solutions their specific electrical conductivity was measured. Specific electrical conductivity of deionized water used for preparing the mentioned solutions, at $25^{\circ} \mathrm{C}$ was equal to $1.2-2.2 \mu \mathrm{S} / \mathrm{cm}$. The error at these measurements was $\pm 0.3 \mu \mathrm{S} / \mathrm{cm}$. $\kappa$ of NPAA-OMEAE increases as the concentration (\% wt.) of the solution increases $\left(19^{\circ} \mathrm{C}\right)$ : $0.025 \% 139.4 ; 0.075 \% 369.1 ; 0.1 \% 524.2 ; 0.5 \%$ 2516.4; $0.7 \% 4060.4 \mu \mathrm{S} / \mathrm{cm}$.

Petroleum-collecting properties of the synthesized complex (in the pure state and in the form of $5 \%$ wt. aqueous solution) has been studied on the example of crude oil from the Pirallahi oil field in the Absheron Peninsula (Azerbaijan). The surfactant $(0.02 \mathrm{~g})$ or its solution was added to a thin film (thickness $0.15-0.16 \mathrm{~mm}$ ) of this petroleum on the surface of distilled water, fresh water and the Caspian Sea water (separately) in Petri dishes. The maximum values of the petroleum collecting coefficient $(\mathrm{K})$ are calculated using the formula $\mathrm{K}=\mathrm{S}_{\mathrm{o}} / \mathrm{S}$, where $S_{o}$ is an area of the surface of initial petroleum film and $S$ is an area of the surface of accumulated petroleum (as a thickened spot). Since the moment of the surfactant application observations are carried out with measurement of the spot surface area and determination of the $\mathrm{K}$ values at fixed time intervals. The tests were carried out in three types of water having various degrees of mineralization. Three types of water were used: distilled, fresh (hardness $4.2 \mathrm{mg}$ equiv/L), and sea water. Water of the Caspian sea had the following characteristics: $\mathrm{q} 20=1.0098 \mathrm{~g} / \mathrm{mL}, \mathrm{pH}=7.7$. Its composition is as following (mg/L): $\mathrm{Na}^{+} 2650 ; \mathrm{K}^{+} 90 ; \mathrm{Ca}^{2+} 250 ; \mathrm{Mg}^{2+} 900$ $\mathrm{NH}_{4}{ }^{+} 0.15 ; \mathrm{Cl}^{-} 500 ; \mathrm{SO}_{4}{ }^{2-} 2800 ; \mathrm{NO}_{3}{ }^{-} 0.1 ; \mathrm{PO}_{4}{ }^{3-} 0.35$; $\mathrm{NO}_{2}^{-}$0.007; $\mathrm{SiO}_{2}$ 0.5; oil products $-0.005 \%$; dissolved oxygen $8 \mathrm{mg} / \mathrm{L}$. Total hardness is $69.0 \mathrm{mg}$ eq/L. (Tabel 1).

Table 1.

Petroleum-collecting properties of the surfactant-polymeric complexes based on NPAA and OMEAE

\begin{tabular}{|c|c|c|c|c|c|c|}
\hline \multirow{2}{*}{ Surfactant } & \multicolumn{2}{|c|}{ Distilled water } & \multicolumn{2}{|c|}{ Fresh water } & \multicolumn{2}{|c|}{ Sea water } \\
\hline & $\tau, \mathbf{h}$ & $\mathbf{K}$ & $\tau, \mathbf{h}$ & $\mathbf{K}$ & $\tau, \mathbf{h}$ & $\mathbf{K}$ \\
\hline \multicolumn{7}{|c|}{ Polymer complex of OMEAE with NPAA } \\
\hline Undiluted product & $\begin{array}{c}0-0.5 \\
1.0-2.0 \\
3.0-15.0 \\
24.0-156.0\end{array}$ & $\begin{array}{l}30.5 \\
53.2 \\
60.8 \\
80.5 \\
\end{array}$ & $\begin{array}{c}0-0.5 \\
1.0-2.0 \\
3.0-15.0 \\
24.0-172.0\end{array}$ & $\begin{array}{l}38.7 \\
45.6 \\
58.9 \\
60.8 \\
\end{array}$ & $\begin{array}{c}0-0.5 \\
1.0-2.0 \\
3.0-15.0 \\
24.0-168.0\end{array}$ & $\begin{array}{l}30.5 \\
58.9 \\
60.8 \\
80.5 \\
\end{array}$ \\
\hline $5 \%$ wt. solution & $\begin{array}{c}0-0.5 \\
1.0-2.0 \\
3.0-156.0\end{array}$ & $\begin{array}{l}38.7 \\
40.5 \\
76.4 \\
\end{array}$ & $\begin{array}{c}0-0.5 \\
1.0-2.0 \\
3.0-172.0\end{array}$ & $\begin{array}{l}40.5 \\
56.3 \\
60.8 \\
\end{array}$ & $\begin{array}{c}0-0.5 \\
1.0-2.0 \\
3.0-168.0\end{array}$ & $\begin{array}{l}38.7 \\
60.8 \\
79.8 \\
\end{array}$ \\
\hline
\end{tabular}

This surfactant has a high petrocollecting capacity. When it is applied in unthinned form and used as a $5 \%$ aqueous solution this polymer complex demonstrates high values of petrocollecting coefficient. Maximum value of $\mathrm{K}$ equals 80.2 , the time of the reagent action exceeding 172 hours.

\section{Reference:}

1. Ramachandran S.D., Hodson P.V., Khan C.W. et al. Oil dispersant increases PAH uptake by fish exposed to crude oil // Ecotoxicol Environ Saf. 2004, pp. 300-308.

2. Asadov Z.H., Poladova T.A., Salamova N.V. et al. New surface-active polymer complexes based on dodecylammonium caprinate and pelargonate salts. Polish Journal Of Science, 2020, №23, pp. 15-21.

3. Lessard R.R., De Marco G. The significance of oil spill dispersants // Spil. Sci. Technol., 2000, pp. 659-668.

4. Qian Guodong, ZhaoYupeng, RenXuhe et al. Effectiveness Evaluation Technology of New Environment-friendly Oil Spill Dispersant // Aquatic Procedia, 2015, pp. 245-253.

5. Asadov Z.H., Poladova T.A., Salamova N.V. New surface-active polymeric complexes for cleaning sea surface from thin petroleum slicks. Znanstvena misel journal, 2020, № 38, Vol.1. pp.12-15. 